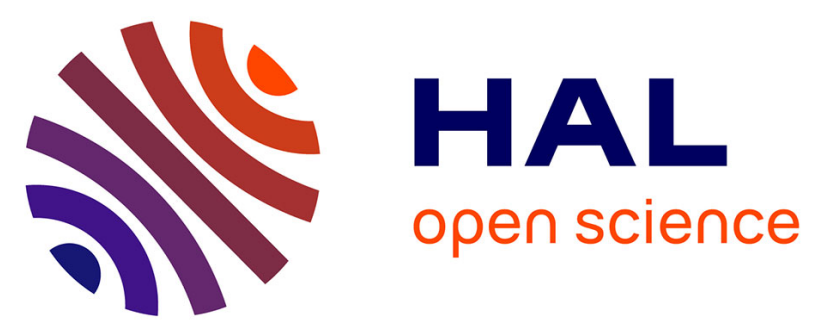

\title{
Recovery of meiofauna communities following mudflat disturbance by trampling associated with crab-tiling
}

Gareth E.L. Johnson, Martin J. Attrill, Emma V. Sheehan, Paul J. Somerfield

\section{To cite this version:}

Gareth E.L. Johnson, Martin J. Attrill, Emma V. Sheehan, Paul J. Somerfield. Recovery of meiofauna communities following mudflat disturbance by trampling associated with crab-tiling. Marine Environmental Research, 2007, 64 (4), pp.409. 10.1016/j.marenvres.2007.03.002 . hal-00501913

\section{HAL Id: hal-00501913 https://hal.science/hal-00501913}

Submitted on 13 Jul 2010

HAL is a multi-disciplinary open access archive for the deposit and dissemination of scientific research documents, whether they are published or not. The documents may come from teaching and research institutions in France or abroad, or from public or private research centers.
L'archive ouverte pluridisciplinaire HAL, est destinée au dépôt et à la diffusion de documents scientifiques de niveau recherche, publiés ou non, émanant des établissements d'enseignement et de recherche français ou étrangers, des laboratoires publics ou privés. 


\section{Accepted Manuscript}

Recovery of meiofauna communities following mudflat disturbance by tram pling associated with crab-tiling

Gareth E.L. Johnson, Martin J. Attrill, Emma V. Sheehan, Paul J. Somerfield

PII:

S0141-1136(07)00043-8

DOI:

10.1016/j.marenvres.2007.03.002

Reference:

MERE 3110

To appear in:

Marine Environmental Research

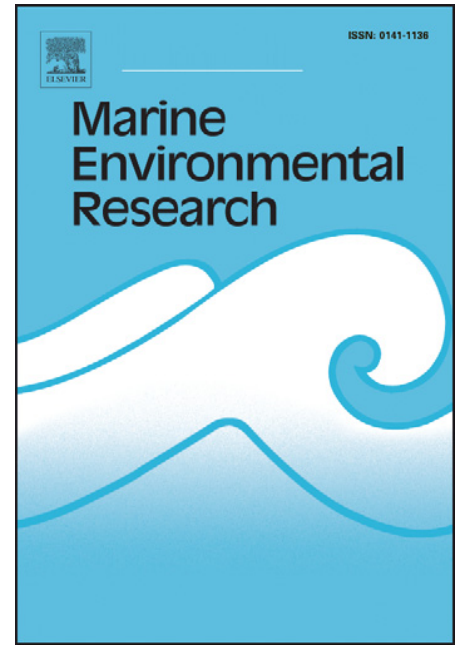

Received Date: $\quad 15$ January 2007

Revised Date: $\quad 6$ March 2007

Accepted Date: $\quad 7$ March 2007

Please cite this article as: Johnson, G.E.L., Attrill, M.J., Sheehan, E.V., Somerfield, P.J., Recovery of meiofauna communities following mudflat disturbance by trampling associated with crab-tiling, Marine Environmental Research (2007), doi: 10.1016/j.marenvres.2007.03.002

This is a PDF file of an unedited manuscript that has been accepted for publication. As a service to our customers we are providing this early version of the manuscript. The manuscript will undergo copyediting, typesetting, and review of the resulting proof before it is published in its final form. Please note that during the production process errors may be discovered which could affect the content, and all legal disclaimers that apply to the journal pertain. 
Recovery of meiofauna communities following mudflat disturbance by trampling associated with crab-tiling

Gareth E.L. Johnson ${ }^{1,2, \dagger}$, Martin J. Attrill ${ }^{1}$, Emma V. Sheehan ${ }^{1}$, Paul J. Somerfield ${ }^{2}$

${ }^{1}$ Marine Biology and Ecology Research Centre, Marine Institute, University of Plymouth, Drake Circus, Plymouth PL4 8AA, UK

${ }^{2}$ Plymouth Marine Laboratory, Prospect Place, Plymouth, PL1 3DH, UK

$\dagger$ current address: School of Ocean Sciences, University of Wales, Bangor, Menai Bridge, Anglesey, LL59 5AB, UK. Email: osp401@ bangor.ac.uk

Tel: +44 (0)1752 232900

Fax: $+44(0) 1752232970$ 


\section{Abstract}

The provision of artificial shelters for the collection of crabs, known as crab-tiling, and the subsequent harvesting of the soft "peeler" crabs for angling bait, are associated with trampling disturbance of intertidal mudflats in the United Kingdom. Recovery of meiofauna communities following crab-tiling activity was investigated on an intertidal mudflat in SW England. Harvesting of experimental plots was reproduced 6 times over a 2-week period. Meiofauna was collected at low tides $12 \mathrm{~h}$, $36 \mathrm{~h}$ and $144 \mathrm{~h}$ after treatment. Meiofaunal and nematode abundance, and nematode species number, was significantly greater in controls compared to crab-tile stations at $12 \mathrm{~h}$. At 36 and $144 \mathrm{~h}$ there were no significant differences between treatments, indicating recovery had occurred in 12-36 h. Multivariate analysis showed nematode assemblage composition from control plots to be significantly different from crab tile plots at $12 \mathrm{~h}$. No significant differences were observed between sediment physical parameters with treatment. Results suggest that the predominant effect of disturbance may be vibration-induced burial, which causes nematodes to bury deeper into the sediment, beyond the depth sampled, and explains the rapid recovery.

KEY WORDS: Meiofauna, Recovery, Crab-tiling, Disturbance, Nematodes 


\section{Introduction}

Collection of bait for anglers is a common practice along many UK shores (Fowler, 1999). Prior to moulting, green shore crabs (Carcinus maenas L.) have soft shells and are known as 'peelers' or 'softbacks' (Cook et al., 2002). They seek refuge under structures on the shore because of their vulnerable state. Peeler crabs are believed to release pheromones which attract fish, making them popular as bait. Crab-tiling involves the placement of structures along foreshores of estuaries under which moulting $C$. maenas seek shelter, making it easy to harvest them at low tide. Crab tiles can be materials such as concrete roofing tiles laid on the sediment or pieces of plastic guttering inserted into the sediment.

With an increase in sea angling in the UK in recent years there has been a subsequent increase in demand for good bait, leading to an expansion in the use of artificial shelters to increase crab catches on soft sediment shores. The increased deployment of artificial shelters has led to concerns about possible impacts on crab populations and estuarine ecosystems (Fowler, 1999). There is particular worry because intertidal flats and saltmarshes are important components of coastal systems, providing food for many commercially important populations of invertebrates, fish and, in particular, birds (Ray, 2000). Crab-tiling has the potential to affect estuarine ecosystems in a number of ways: direct mortality to benthos may be caused by operator trampling (Chandrasekara and Frid, 1996; Wynberg and Branch, 1997); crab stocks may be depleted (Cook et al., 2002); placement of tiles could disturb sediment and alter bed topography and hydrodynamics (Young and Southard, 1978; Thrush et al., 1992); increased crab populations on small spatial and temporal scales may increase predation and bioturbation (Schratzberger and Warwick 1999); and 
trampling of sediment during collection might alter habitat characteristics (Brosnan and Crumrine, 1994).

Meiofaunal organisms are highly abundant in intertidal sediments. They are characterised by direct benthic development, with the whole of their life-cycle closely coupled to the sediment, no specific dispersal phase, and generation times very much less than one year. Free-living nematodes are the numerically dominant group of Metazoa in the majority of marine sediment ecosystems. Warwick (1988) and colleagues (Heip et al., 1988) hypothesised that aspects of their ecology might make them more sensitive to rapid changes in the environment, compared to the majority of macrofaunal organisms which often live for more than a year, and often have a planktonic phase in their life-cycle. It was further hypothesised (Warwick et al., 1990) that meiofauna are less sensitive to physical disturbance than macrofauna. This was followed up by experimental studies (Schratzberger and Warwick, 1998; 1999) which demonstrated, inter alia, that nematodes are sensitive to the nature, frequency and quantity of disturbance, but that different assemblages may be predisposed to disturbance.

We undertook a field experiment to determine: the effects of crab-tiling activity on nematode assemblages within an estuarine mudflat typical of those generally used for bait collection in SW England and, specifically to determine the time required for nematode assemblages to recover from associated disturbance.

\section{Materials and methods}

Experimental plots were assembled on a tidal flat at Shortafleet Creek in the Yealm Estuary, Devon, S.W. England (Fig. 1). Two grids, $10 \mathrm{~m} \mathrm{x} 10$ m, were 
constructed $40 \mathrm{~m}$ from each other at the same tidal height. Grids were divided into 1 $\mathrm{m}^{2}$ plots that were randomly allocated treatments: control plots $(\mathrm{n}=8)$ were left untouched for the course of the experiment; guttered and trampled plots $(n=8)$ had plastic guttering inserted into the sediment at each corner and were then subjected to trampling 6 times over a 2-week period. Trampling was undertaken in a manner to simulate the movement of operators collecting crabs from under tiles.

Samples were taken 12, 36 and $144 \mathrm{~h}$ after the last trampling. 2 replicates of each treatment were taken from each grid on each sampling occasion. Meiofauna was sampled to a depth of $11 \mathrm{~cm}$ using a $2 \mathrm{~cm}$-diameter core with a resulting volume of $34.6 \mathrm{~cm}^{3}$, and then fixed in $10 \%$ formalin. Sediment was collected for analysis using a $5 \mathrm{~cm}$ diameter core to a depth of $11 \mathrm{~cm}$. In each sampled plot, penetrability of the sediment (i.e. how firmly packed it is) was measured by dropping a $1 \mathrm{~m}$ iron rod from a height of $20 \mathrm{~cm}$ and measuring its penetration into the sediment (Wynberg and Branch, 1994); the average of three replicates was calculated.

In the laboratory, meiofaunal extraction and mounting methods followed Somerfield and Warwick (1996) and Somerfield et al. (2005). Briefly, cores were washed through a $500 \mu \mathrm{m}$ sieve overlying a $63 \mu \mathrm{m}$ sieve to remove formalin and larger sediment particles, and the fauna extracted by flotation using Ludox-TM with a specific gravity of $1.15 .5 \%$ sub-samples were taken and washed into cavity blocks using a mixture of $5 \%$ glycerol and $10 \%$ ethanol. The cavity blocks were left on a warm hotplate overnight to evaporate to pure glycerol. Material from each sample was transferred to a prepared microscope slide with a rectangular paraffin wax ring. A coverslip was added over the wax ring, which was carefully melted to seal the slide, and the preparation was ringed with Bioseal No. 2 mountant. Meiofauna was counted and identified under a compound microscope with conventional bright-field 
illumination. Nematodes were identified to species, or putative species, using appropriate keys (Platt and Warwick, 1983; 1988; Warwick et al., 1997).

A Malvern Long-bed Mastersizer X laser particle sizer was used to analyse sediment grain size. Three subsamples were taken and larger particle sizes (4-2000 $\mu \mathrm{m})$ were measured using a $1000 \mathrm{~mm}$ lens. Smaller $(0.1-80 \mu \mathrm{m})$ particles were analysed in a fourth subsample using a $45 \mathrm{~mm}$ lens. For organic-matter determination, sediment samples were dried at $60{ }^{\circ} \mathrm{C}$ for $24 \mathrm{~h}$, weighed, combusted at $450{ }^{\circ} \mathrm{C}$ for $24 \mathrm{~h}$, and reweighed to determine ash-free dry weight.

For univariate statistical analyses, normality and homogeneity of variances were determined using Anderson-Darling's and Cochran's tests and, where appropriate, transformations $(\ln (\mathrm{x}+1))$ applied. All analyses between plots for each time period were found to be non-significant (all $F_{1,8}<3.31$, all $p>0.143$ ), so to allow for a more powerful test, data were pooled and analyses consisted of a series of 1-way ANOVA tests (treatment at each time period). Formal 2-way ANOVA was not considered appropriate as time periods needed to be considered separately to determine when recovery was complete; the time periods are not true replicates as the assumptions about differences will vary with time (and thus hypotheses). Additionally, 2-way analysis in this context would rely primarily on post-hoc pairwise tests to assess differences within time-treatment interactions. Due to the comparatively low power of such an approach (in respect to ANOVA), this method increases the chances of Type II errors. All univariate analyses were conducted using MINITAB 13.

PRIMER 6 was used for non-parametric multivariate analyses (Clarke, 1993; Clarke and Gorley, 2006). Nematode abundances were dispersion-weighted to downweight contributions to intersample similarities from species with significant overdispersion (Clarke et al., 2006a). Intersample similarities were calculated using 
an adjusted form of the Bray-Curtis similarity coefficient (Clarke et al., 2006b) as some samples contained very low abundances and it could be assumed that these were depauperate for similar reasons. Intersample similarities were ordinated using non-metric multidimensional scaling (MDS). Environmental variables were normalised (by subtracting the mean and dividing by the standard deviation) to convert them to a standard scale, and dissimilarities between samples calculated using Euclidean distance (Clarke et al., 2006b). Formal significance tests for differences between groups of samples were addressed using ANOSIM (analysis of similarity) permutation tests. A series of 1-way tests were used to test for differences between treatments at different times, following the logic of the ANOVA analyses. Species contributing to dissimilarities between groups of samples were examined using the similarities percentage (SIMPER) procedure (Clarke, 1993).

\section{Results}

In higher-way analyses of abiotic and biotic data, there were no significant differences (all $\mathrm{p}>0.05$ ) between grids, and samples were treated as replicates for subsequent analyses. Differences in abiotic factors (grain size, total organic content and penetrability) between control and crab-tile plots were not significant at any time during the experiment; multivariate analyses indicated no effect of treatment or time (ANOSIM Global $R=0.066, p=0.185$ ).

Nematoda was the dominant meiofaunal taxon in the mudflat, comprising $83.1 \%$ of individuals on average and accounting for up to $100 \%$ in some samples. Copepoda contributed $17.7 \%$ of the meiofauna on average, while small numbers $(<3$ $\mathrm{cm}^{-3}$ ) of Polychaeta, Ostracoda, Acari, Oligochaeta and Kinorhyncha made up the 
rest. Meiofaunal abundance was significantly greater in control compared to crab-tile plots at $12 \mathrm{~h}$ (ANOVA: $\left.F_{1,32}=17.85, p=0.006\right)$ but differences between treatments were not significant at $36\left(F_{1,32}=0.05, p=0.835\right)$ and $144 \mathrm{~h}\left(F_{1,32}=0.79, p=0.408\right)$.

4172 individuals distributed among 43 nematode taxa were identified (Table 1). 15 taxa (35\%) were significantly overdispersed, indicating clumped spatio-temporal distributions (variance:mean ratio $>1, p<0.05$ ), and were therefore downweighted in multivariate analyses (Table 1). Terschellingia communis and Terschellingia longicaudata were the most abundant species, together comprising $47 \%$ of individuals per sample on average. The next most abundant species were Ptycholaimellus ponticus (15\%), Axonolaimus paraspinosus (7\%) and Sabatieria pulchra $(6 \%)$. Numbers of nematode individuals $(\mathrm{N})$ and species $(\mathrm{S})$ were significantly lower in crab-tile plots compared to control plots at $12 \mathrm{~h}$ (ANOVA, N: $\left.F_{1,32}=9.69, p=0.021 ; \mathrm{S}: F_{1,32}=13.9, p=0.01\right)$. At 36 and $144 \mathrm{~h}$, differences between treatments were not significant.

Nematode assemblage composition in the crab-tiled plots at $12 \mathrm{~h}$ differed from that in the control plots (ANOSIM $R=0.594, p=0.029$, Fig. 2). Differences in nematode assemblages between treatments had disappeared at 36 and $144 \mathrm{~h}(R=-0.083, p=$ $0.771 ; R=0.302, p=0.114)$. Differences between times within crab-tiled plots were, as expected, significant $(R=0.641, p=0.001)$, reflecting differences between samples from $12 \mathrm{~h}$ and those collected at 36 and $144 \mathrm{~h}$. Samples collected at 36 and 144 h did not differ significantly, however $(R=0.26, p=0.089)$. Less expectedly, control samples also varied significantly through time $(R=0.571, p=0.001)$, again reflecting differences between samples collected at $12 \mathrm{~h}$ and those collected at 36 and $144 \mathrm{~h}$, which did not differ from each other $(R=0.24, p=0.171)$. 
Species contributing to differences between treatments at $12 \mathrm{~h}$ were all less abundant in, or absent from, crab-tiled plots (Table 1). The suites of species contributing to differences between control plots from 12 and $36 \mathrm{~h}$, and crab-tiled plots from 12 and $36 \mathrm{~h}$, were all similar and generally comprised the more abundant species on the mudflat.

\section{Discussion}

Resilience of an ecosystem can be defined as "the degree, manner and pace of restoration of initial structure and function after disturbance" (Westman, 1978). The most easily defined characteristic of ecosystem resilience is the rate of restoration (Sherman and Coull, 1980). Within 12-36 h of crab-tiling activities ending, significantly lower nematode abundance and species numbers had recovered to control levels. Multivariate analysis showed nematode assemblage composition in crab-tile plots to be comparable to controls after $36 \mathrm{~h}$. The sampled intertidal mudflat meiofaunal communities can, therefore, be defined as resilient. This is supported by previous studies, which found meiofaunal recovery times from physical disturbance to vary between $12-48 \mathrm{~h}$, depending on habitat type (Sherman and Coull, 1980; Hockin, 1982; Mistri et al., 2004).

The intermediate disturbance hypothesis links recovery rates to prevalent background disturbance regimes and habitat stability (Connell, 1978). Communities frequently exposed to physical perturbations tend to recover more quickly as they are dominated by species adapted to life in a dynamic environment (Gorzelany and Nelson, 1987). Marine assemblages in subtidal sands recover from physical disturbance more quickly than those in subtidal muds; the natural background 
disturbance regime in the former is more energetic, so communities have adapted to high levels of natural disturbance (Kaiser, 1998; Collie et al., 2000). Microcosm studies indicate that nematode assemblages from sandy sediments are more resilient to physical perturbations than those from muddy sediments (Schratzberger and Warwick, 1998). However, unlike subtidal muds, intertidal mudflats are exposed to frequent natural disturbance, through tidal forces and currents, and the habitat is structured by these recurrent physical perturbations. Therefore mudflat communities, exposed naturally to repeat disturbances, may be expected to recover rapidly.

Abiotic factors indicate that crab tiling induced no significant changes to habitat structure. Recovery times can be longer when habitat characteristics are modified, and may take as long as $168 \mathrm{~h}$ when altered sediment characteristics persist (Cross and Curran, 2004). In these circumstances, some level of habitat recovery may be required before communities can recover (Dernie et al., 2003a; 2003b).

Due to the small-scale disturbance imposed by crab-tiling activity, it is probable that at least some recolonisation occurred via passive transport from densely populated adjacent sediment. Local dispersal is an important factor aiding persistence of populations following small-scale physical disturbance (Hiebeler, 2000) and recovery rate is related to the degree of community isolation (Chandler and Fleeger, 1983; Smith and Brumsickle, 1989). Nematodes and copepods are both passively resuspended and transported by tidal forces and currents (Sherman and Coull, 1980), and water-column meiofauna form a dispersing colonist pool that appears commonly in estuaries (Palmer, 1988) and allows rapid recolonisation of sediments (Sun and Fleeger, 1994). Meiofauna populations in muddy habitats are predominately located in the upper sediments and may have increased rates of dispersal, particularly as intertidal populations are regularly resuspended by tidal forces (Steyaert et al., 2003). 
However, resuspension does not affect all taxa to the same degree; tidal currents particularly affect the small-scale distribution of harpacticoid copepods and to a lesser extent that of nematodes (Bell and Sherman, 1980).

It has been hypothesised that meiofauna that live close to the sediment surface are more susceptible to erosion and transport than deep dwelling species, so epigrowthfeeders may be expected to have relatively high dispersal rates, and populations may recover more rapidly following disturbance (Warwick and Gee, 1984).

Ptycholaimellus ponticus was a dominant species in both control and crab-tile plots, and has previously been found to quickly recolonise organically enriched sediment (Schratzberger et al., 2004a). That being said, the observed response to crab-tiling was a decreased abundance and range of species with differing feeding modes and ecological strategies, suggesting that whatever the direct effect of crab-tiling was, it had no species-specific component. The fact that control plots also had reduced abundances which recovered within $36 \mathrm{~h}$ suggests that the applied treatment had more widespread effects than expected, and therefore the mechanism by which crab-tiling disturbance reduces abundances cannot simply be via direct mortality.

Many meiofaunal taxa vertically migrate through sediments (Fay and Thistle, 1991; Palmer et al., 1992; Schratzberger et al., 2000) and vibrations through sediments may cause nematodes to bury deeper (Schratzberger et al., 2004a). Trampling of the sediment may have induced nematode populations to sink below the level of sampling, and this may be the reason for the apparent impact of, and recovery from, disturbance in the control plots. If disturbance intensity determined the depth of burial and number of nematodes that bury, then populations may have buried deeper in crab-tile plots where trampling occurred overhead, but also buried to a lesser extent in nearby controls. If nematode recolonisation of small-scale 
defaunations is predominately via the same infaunal migration (Chandler and Fleeger, 1983; Schratzberger et al., 2004b), this would explain the rapid restoration of populations and may explain why community effects were not species specific.

Taking deeper cores and vertical profiles of meiofauna communities would provide a better understanding of the mechanisms of impact and recovery by separating vertical migration and passive tidal transport in future studies.

\section{Acknowledgements}

This work is a contribution to the marine biodiversity programme of the Plymouth Marine Laboratory, and was undertaken as part of the requirements for a MSc jointly with University of Plymouth by GELR. We thank S. Dashfield and H. Needham for laboratory assistance. PJS acknowledges support from Defra (ME3109); MJA and EVS support from the Holly Hill Charitable Trust.

\section{References}

Bell, S.S., Sherman, K.M. 1980. A field investigation of meiofaunal dispersal: tidal resuspension and implications. Marine Ecology Progress Series 73, 61-68.

Brosnan, D.M., Crumrine, L.L. 1994. Effects of human trampling on marine rocky shore communities. Journal of Experimental Marine Biology and Ecology 177, 190-197. 
Chandler, T.G., Fleeger, J.W. 1983. Meiofaunal colonisation of azoic estuarine sediment in Louisiana: mechanisms of dispersal. Journal of Experimental Marine Biology and Ecology 69, 175-18.

Chandrasekara, W.U., Frid,C.L.J. 1997. Effects of human trampling on tidalflat infauna. Aquat Conserv, Marine and Freshwater Ecoystems 7, 299-311.

Clarke, K.R. 1993. Non-parametric multivariate analyses of changes in community structure. Austalian Journal of Ecology 18, 117-143.

Clarke, K.R., Chapman, M.G., Somerfield, P.J., Needham, H.R. 2006a. Dispersionbased weighting of species counts in assemblage analyses. Marine Ecology Progress Series 320, 11-27.

Clarke, K.R., Gorley, R.N. 2006. PRIMER v6: User manual/tutorial. Primer-E, Plymouth.

Clarke, K.R., Somerfield, P.J., Chapman, M.G. 2006b. On resemblance measures for ecological studies, including taxonomic dissimilarities and a zero-adjusted Bray-Curtis measure for denuded assemblages. Journal of Experimental Marine Biology and Ecology 330, 55-80.

Collie, J.S., Hall, S.J., Kaiser, M.J., Poiner, I.R. 2000. A quantitative analysis of fishing impacts on shelf-sea benthos. Journal of Animal Ecology 69, 785-798.

Connell, J.H. 1978. Diversity in tropical rainforests and coral reefs. Science 99, 13021310.

Cook, W., Jones, E., Wyn, G., Sanderson, W.G. 2002. Experimental studies on the effects of shore crab collection using artificial shelters on an intertidal sandflat habitat. Countryside Council for Wales, Contract Science Report no. 511.

Cross, R.E., Curran, M.C. 2004. Recovery of meiofauna in intertidal feeding pits created by rays. Southeastern Naturalist 3, 219-230. 
Dernie, K.M., Kaiser, M.J., Richardson, E.A., Warwick, R.M. 2003a. Recovery of soft sediment communities and habitats following physical disturbance. Journal of Experimental Marine Biology and Ecology 285/286, 415-434.

Dernie, K.M., Kaiser, M.J., Warwick, R.M. 2003b. Recovery rates of benthic communities following physical disturbance. Journal of Animal Ecology 72, 1043-1056.

Fowler, S.L. 1999. Guidelines for managing the collection of bait and other shoreline animals within the UK and European marine sites. English Nature, UK Marine SACs Project Report, Peterborough.

Gorzelany, J.F., Nelson, W.G. 1987. The effects of beach replenishment on the benthos of a subtropical Florida beach. Marine Environmental Research 21, 75-94.

Hiebeler, D. 2000. Populations on fragmented landscapes with spatially structures heterogeneities: landscape generation and local dispersal. Ecology 81, 16291641.

Heip, C., Warwick, R.M., Carr, M.R., Herman, P.M.J., Huys, R., Smol, N., Van Holsbeke, K. 1988. Analysis of community attributes of the benthic meiofauna of Friersfjord/Langesundfjord. Marine Ecology Progress Series $46,171-180$.

Hockin, D.C. 1982. Experimental insular zoogeography: some tests of the equilibrium theory using meiobenthic harpacticoid copepods. Journal of Biogeography 9, 487-498.

Kaiser, M.J. 1998. Significance of bottom fishing disturbance. Conservation Biology $12,1230-1235$. 
Mistri, M., Cason, E., Munari, C., Rossi, R. 2004. Disturbance of a soft-sediment meiobenthic community by clam hand raking. Italian Journal of Zoology 71, $131-133$

Palmer, M.A. 1988. Dispersal of marine meiofauna: a review and conceptual model explaining passive transport and active emergence with implications for recruitment. Marine Ecology Progress Series 48, 81-91.

Platt, H.M., Warwick, R.M. 1983. Free-living marine nematodes. Part I. British Enoplids. Cambridge University Press, Cambridge

Platt, H.M., Warwick, R.M. 1988. Free-living marine nematodes. Part II. British Chromadorids. Brill, Leiden

Ray, G.L. 2000. Infaunal assemblages on constructed intertidal mudflats at Jonesport, Maine (USA). Marine Pollution Bulletin 40, 1186-1200.

Schratzberger, M., Bolam, S.G., Whomersley, P., Warr, K., Rees, H.L. 2004a. Development of a meiobenthic community following the intertidal placement of various types of sediment. Journal of Experimental Marine Biology and Ecology 303, 79-96.

Schratzberger, M., Rees, H.L., Boyd, S.E. 2000. Effects of simulated deposition of dredged material on structure of nematode assemblages - the role of burial. Marine Biology 136, 643-650.

Schratzberger, M., Warwick, R.M. 1998. Effects of physical disturbance on nematode communities in sand and mud: a microcosm experiment. Marine Biology 130, 643-650.

Schratzberger, M., Warwick, R.M. 1999. Impact of predation and sediment disturbance by Carcinus maenas (L.) on free-living nematode community structure. Journal of Experimental Marine Biology and Ecology 235, 255-271. 
Schratzberger, M., Whomersley, P., Warr, K., Bolam, S.G., Rees, H.L. $2004 b$.

Colonisation of various types of sediment by estuarine nematodes via lateral infaunal migration: a laboratory study. Marine Biology 145, 69-78.

Sherman, K.M., Coull, B.C. 1980. The response of meiofauna to sediment disturbance. Journal of Experimental Marine Biology and Ecology 46, 59-71.

Smith, C.R., Brumsickle, S.J. 1989. The effects of patch size and substrate isolation on colonisation modes and rates in an intertidal sediment. Limnology and Oceanography 34, 1263-1277.

Somerfield, P.J., Warwick, R.M. 1996. Meiofauna in marine pollution monitoring programmes. A laboratory manual. Ministry of Agriculture, Fisheries and Food, Directorate of Fisheries Research, Lowestoft.

Somerfield, P.J., Warwick, R.M., Moens, T. 2005. Chapter 6: Meiofauna Techniques. In: Eleftheriou, A., McIntyre, A. (Eds.), Methods for the study of Marine Benthos, 3rd Edition. Blackwell Science Ltd, Oxford, pp. 229-272.

Steyaert, M., Vanaverbeke, J., Vanreusel, A., Barranguet, C., Lucas, C., Vincx, M. 2003. The importance of fine-scale, vertical profiles in characterising nematode community structure. Estuarine Coastal and Shelf Science 58, 353366.

Sun, B., Fleeger, J.W. 1994. Field experiments on the colonisation of meiofauna into sediment depressions. Marine Ecology Progress Series 110, 167-175.

Thrush, S.F., Pridmore, R.D., Hewitt, J.E., Cummings, V.J. 1992. Adult infauna as facilitators of colonisation on intertidal sandflats. Journal of Experimental Marine Biology and Ecology 159, 253-265.

Warwick, R.M. 1988. Effects on community structure of a pollution gradient summary. Marine Ecology Progress Series 46, 207-211. 
Warwick, R.M., Gee, J.M. 1984. Community structure of estuarine meiobenthos. Marine Ecology Progress Series 18, 97-111.

Warwick, R.M., Platt, H.M., Clarke, K.R., Agard, J., Gobin, J. 1990. Analysis of macrobenthic and meiobenthic community structure in relation to pollution and disturbance in Hamilton Harbour, Bermuda. Journal of Experimental Marine Biology and Ecology 138, 119-142.

Warwick, R.M., Platt, H.M., Somerfield, P.J. 1997. Free-living marine nematodes. Part III. British Monohysterids. Field Studies Council, Shrewsbury.

Westman, W.E. 1978. Measuring the inertia and resilience of ecosystems. Bioscience 28, 705-710.

Wynberg, R.P., Branch, G.M. 1994. Disturbance associated with bait-collection for sandprawns (Callianassa kraussi) and mudprawns (Upogebia africana): Long- term effects on the biota of intertidal sandflats. Journal of Marine Research 52, 523-558.

Wynberg, R.P., Branch, G.M. 1997. Trampling associated with bait-collection for sandprawns Callianassa kraussi Stebbing: effects on the biota of an intertidal sandflat. Environmental Conservation 24, 139-148.

Young, R.N., Southard, J.B. 1978. Erosion of fine-grained marine sediments: Seafloor and laboratory experiments. Geological Society of America Bulletin 89, 663-672. 
Table 1. Total abundance $(\mathrm{N})$ of species in all samples, and average variance:mean ratio (D). ${ }^{*}=$ Significantly overdispersed species $(\mathrm{D}>1, \mathrm{P}<0.05$ in an exact permutation test). SIMPER results: average raw abundances of species contributing up to a cumulative $90 \%$ of dissimilarities between crab-tiled (T) and control (C) samples at $12 \mathrm{~h}$, crab-tiled samples at 12 and $36 \mathrm{~h}$, and control samples at 12 and 36 h. $>,<$ denote species contributing more than $5 \%$ of dissimilarity between groups. For the analysis overdispersed species $(*)$ were downweighted by the value of $D$.

\begin{tabular}{|c|c|c|c|c|c|c|c|c|c|}
\hline Species & $\mathrm{N}$ & $\mathrm{D}$ & T36 & & T12 & & C12 & & C36 \\
\hline$\%$ & & & & 90 & & 80 & & 59 & \\
\hline Terschellingia longicaudata & 1041 & 13.1 & * 58.5 & $>$ & 4.2 & $<$ & 18.5 & & 46.0 \\
\hline Terschellingia communis & 1037 & 7.3 & * 61.0 & $>$ & 3.5 & $<$ & 18.7 & $<$ & 43.3 \\
\hline Ptycholaimellus ponticus & 483 & 2.5 & * $\quad 32.7$ & $>$ & 2.0 & $<$ & 7.0 & $<$ & 27.3 \\
\hline Sabatieria pulchra & 258 & 4.3 & * 14.0 & & 1.0 & & 4.3 & & 14.3 \\
\hline Axonolaimus paraspinosus & 227 & 3.0 & * 14.7 & $>$ & 1.0 & & 2.5 & 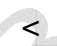 & 11.0 \\
\hline Chromadora sp. & 124 & 2.9 & 6.3 & & 0.5 & $<$ & 4.5 & & 4.0 \\
\hline Atrochromadora sp. & 106 & 1.0 & 6.1 & $>$ & 0.2 & $<$ & 2.2 & $<$ & 7.9 \\
\hline Metachromadora sp. & 91 & 2.8 & 5.8 & & 0.5 & & 1.8 & & 4.7 \\
\hline Desmolaimus zeelandicus & 89 & 3.3 & 4.2 & & 0.0 & & 1.3 & & 5.5 \\
\hline Daptonema setosum & 88 & 2.1 & 5.0 & & 0.2 & 8 & 1.2 & $<$ & 9.2 \\
\hline Daptonema oxycerca & 87 & 1.6 & 2.5 & & 0.0 & 4 & 1.0 & & 2.2 \\
\hline Aponema torosa & 79 & 1.5 & 4.3 & & 0.0 & $<$ & 4.3 & $<$ & 9.3 \\
\hline Tripyloides gracilis & 69 & 1.5 & 5.6 & $>$ & 0.4 & $<$ & 1.9 & & 3.7 \\
\hline Chromadorita tentabunda & 53 & 1.9 & 2.8 & 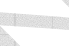 & 0.0 & & 0.5 & & 4.7 \\
\hline Oxystomina elongata & 50 & 1.8 & * & $\Rightarrow$ & & & 0.3 & & 2.5 \\
\hline Leptolaimus papilliger & 44 & 1.2 & 2.9 & & 0.3 & & 0.6 & & \\
\hline Daptonema normandicum & 40 & 1.1 & 2.2 & & 0.3 & & 0.0 & $<$ & 3.9 \\
\hline Halalaimus sp. & 39 & 1.6 & 2.8 & & 0.0 & & 0.8 & & 2.0 \\
\hline Daptonema sp. & 29 & 1.3 & 3.0 & & 0.3 & & 1.3 & & 4.0 \\
\hline Theristus sp. & 23 & 1.5 & & & & & 0.0 & & 1.5 \\
\hline Molgolaimus demani & 21 & 2.2 & * & & & & & & \\
\hline Sabatieria celtica & & 2.9 & * & & & & & & \\
\hline Spirinia sp. & & 1.2 & & & & & & & \\
\hline Microlaimus sp. & 12 & 1.0 & & & 0.0 & & 0.5 & & \\
\hline Paralinhomoeus sp. & 9 & 1.0 & & & & & & & \\
\hline Nudora bipapillata & 7 & 0.8 & & & & & & & \\
\hline Viscosia viscosa & 7 & 1.0 & & & & & & & \\
\hline Sphaerolaimus sp. & 5 & 0.8 & & & & & & & \\
\hline Anoplostoma viviparum & 4 & 2.0 & * & & 0.0 & & 0.8 & & \\
\hline Eleutherolaimus stenosoma & 3 & 1.0 & & & & & & & \\
\hline Linhomoeus sp. & 3 & 1.5 & & & & & & & \\
\hline Dichromadora sp. & 2 & 1.0 & & & & & & & \\
\hline Oncholaimus sp. & 2 & 0.7 & & & & & & & \\
\hline Antomicron elegans & 1 & 1.0 & & & & & & & \\
\hline Axonolaimus spinosus & 1 & 1.0 & & & & & & & \\
\hline Campylaimus sp. & 1 & 1.0 & & & & & & & \\
\hline Cyartonema sp. & 1 & 1.0 & & & & & & & \\
\hline Onyx sp. & 1 & 1.0 & & & & & & & \\
\hline Paracanthonchus sp. & 1 & 1.0 & & & & & & & \\
\hline Praeacanthoncus sp. & 1 & 1.0 & & & & & & & \\
\hline Quadricoma scania & 1 & 1.0 & & & & & & & \\
\hline Rhabditis marina & 1 & 1.0 & & & & & & & \\
\hline Spilophorella paradoxa & 1 & 1.0 & & & & & & & \\
\hline
\end{tabular}




\section{Figure captions}

Figure 1. Location (arrowed) of the crab-tiling experiment near the mouth of the River Yealm in Devon, UK.

Figure 2. Ordination by MDS of adjusted Bray-Curtis similarities calculated from dispersion-weighted nematode abundances in control (filled symbols) and crab-tiled (open symbols) plots at $12(\triangle), 36(\bigcirc)$ and $144(\nabla)$ h. Stress $=0.05$. 


\section{ACCEPTED MANUSCRIPT}

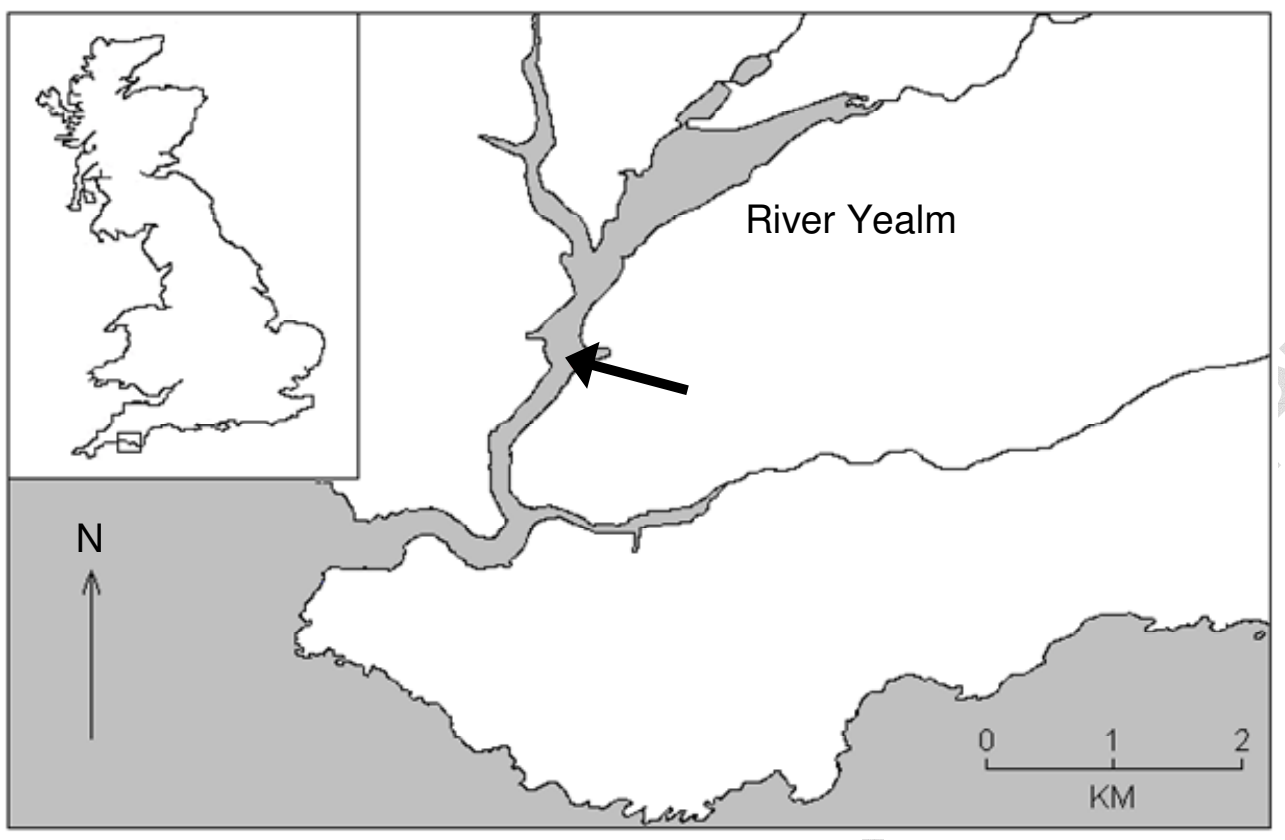

Figure 1 


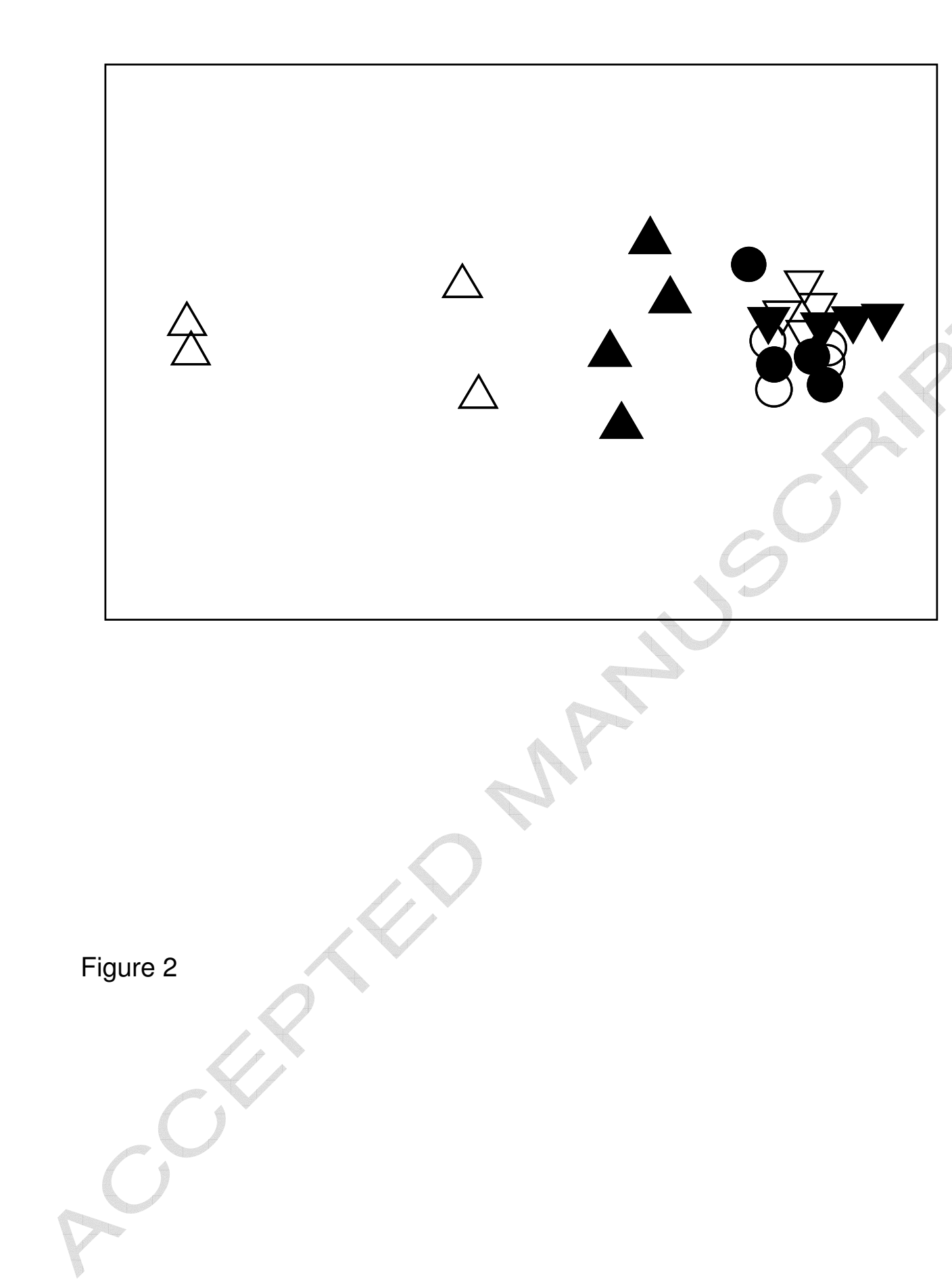

